\author{
Egidijus Gailiūnas ${ }^{*}$ \\ Institute of International Relations and Political Science, Vilnius University
}

\title{
Arab Uprisings and Western Security Interests: a View from Lithuania
}

\begin{abstract}
The wave of Arab uprisings (both non-violent and violent) that started in January 2011 is a remarkable phenomenon that has attracted enormous attention from international media outlets. In fact, the Arab world has not experienced such political and social upheaval in decades. It is no coincidence that many Western countries whose security interests have been closely related to these Arab states found themselves confused by the beginning of the uprisings. Most Western security experts at the beginning were silent. A year or even a couple of months ago almost none of them could have predicted that these Arab countries would go through such deep political and social upheavals that would have such deep ramifications on the security situation in these countries, the region, and far beyond it. Caught off-balance by the Arab uprisings, Western security experts rushed to explain what the causes of the uprisings were. Who are the actors and what are the forces behind the uprisings? The important question still remains - what are the possible consequences of the uprisings for Western interests? Is all the change only about the change of a few ruling persons? Or are we witnessing deeper systematic (and revolutionary) changes in some Arab countries that will have a long-term impact on the West? So far, unambiguous answers to these questions are hard to find. However, some insights related to the questions above can already be made. The aim of this article is to analyze the Arab uprisings, their causes and possible effects on Western and Lithuanian security interests. Will Lithuanian national security be affected by the Arab uprisings? Are uprisings in Tunisia, Egypt, Libya, Syria, Bahrain and other Arab countries important for Lithuanian national security? Can Lithuania ignore the events that are happening in regions far away from Lithuania's borders?
\end{abstract}

\section{Introduction}

Arab countries and the Middle East region ${ }^{1}$ are not commonly researched by members of the Lithuanian academic community. For this reason any Lithuanian researcher who intends to analyze an Arab country or countries risks being misunderstood at home. His or her colleagues might think that he or she lacks the basic understanding of local political and geopolitical realities.

\footnotetext{
* Egidijus Gailiūnas is a PhD candidate of the Institute of International Relations and Political Science, Vilnius University. Address for correspondence: Vokiečių 10, LT-01130 Vilnius, Lithuania, tel. +370-5-2514130, e-mail: gegidijus@gmail.com

${ }^{1}$ In this article North Africa and Persian Gulf are considered to be sub-regions of the Middle East region.
} 
On the other hand, in the age of globalization, it would be unwise for the Lithuanian academic community to stay focused only on the narrow field of scientific research related to domestic policy and political processes in neighboring countries. Actually, the Lithuanian academic community is not focused only on domestic policy and the country's "near abroad". Lithuanian researchers perfectly understand that nowadays political processes even in geographically remote regions can very quickly affect the security situation in Lithuania or in the European Union or in NATO. The September 11 terrorist attacks on New York and Washington, as well as Western military interventions in Afghanistan and Iraq already encouraged members of the Lithuanian academic community to focus on new types of threats (e.g. terrorism) and the Middle East region. Therefore, for Lithuanian political scientists and local international relations experts it would be inappropriate to ignore such internationally important events as the Arab uprisings. It is worth mentioning that the Arab uprisings that have been known in recent months as the "Arab Spring", "Arab revolutions", "Arab Awakening", and "intifadas" are widely discussed in Western academic circles.

Arab uprisings are not ordinary events in the international political arena or in the Arab world. The uprisings that started in January 2011 are often compared to the Spring of Nations of 1848, the Fall of the Berlin Wall in 1989, the liberation of Eastern Europe from Communism, and to the so-called "color revolutions" at the beginning of the twenty-first century. However, according to Habib Malik, historical analogies are cute but misleading; the Arab uprisings are indigenous and unique developments ${ }^{2}$.

It could be argued that all were caught by surprise by the wave of uprisings that ran through the Middle East. It seems that even the Arabs themselves did not expect it. Therefore it is not surprising that at the moment there is little available scientific literature about the Arab uprisings. The impact of the uprisings on Western security interests still needs more attention. For now there is almost no analysis of the impact of Arab uprisings on Lithuania's security interests.

The main aim of this article is to determine the possible impact of the Arab uprisings on Western and Lithuanian security interests. The following questions are raised: How will the Arab uprisings influence Western interests in the Middle East? Are the uprisings in Tunisia, Egypt, Libya, Syria, Bahrain and other Arab countries important for Lithuanian national security? Can Lithuania ignore the events that are happening in regions far away from Lithuania's borders? The search for the answers to these questions starts from a short review of the Arab uprisings themselves.

\footnotetext{
${ }^{2}$ Malik H., "Is It the Arab Spring?”, USA: Johns Hopkins University, 3003 2011, http://www.sais-jhu.edu/ bin/k/i/Is_It_The_Arab_Spring_30-3-11.pdf, 15042011.
} 


\section{Anatomy of the Arab Uprisings}

It is difficult to begin an analysis of the Arab uprisings and their impact on Western interests without knowing some basic information about the uprisings - their beginning, sequence of events, causes, and possible effects on the Middle East region. Thus, this section is a kind of anatomy of the Arab uprisings. True, this anatomy is not and cannot be complete, since the Arab uprisings are still evolving.

The starting point of the Arab uprisings is generally considered to be December 17, 2010. On that day Mohamed Bouazizi, a resident of the Tunisian town of Sidi Bouzid, decided to set himself on fire in public in order to protest the confiscation of his wares and the harassment he endured from public officials $s^{3}$. At first glance, Bouazizi's actions, caused by economic and social grievances, seemed to have little political significance. It was a personal act of desperation. It happened in a relatively small town and not in the capital of Tunisia. In the Middle East and even in Tunisia, it was not the first time that someone chose to immolate himself in the name of protest ${ }^{4}$. These previous acts of self-immolation did not attract a great deal of media attention. Nonetheless, Bouazizi's act of despair unexpectedly led to politically and strategically important and unpredictable events that shook the entire Middle East region. Bouazizi became the symbol of uprisings against Middle Eastern autocratic regimes that prohibit mass protests and political activism in general. Bouazizi's act of resistance led not only to large-scale protests in Tunisia; it also inspired many thousands of Arabs to go to the streets from Mauritania to Oman. Thanks to Bouazizi, after decades of absence the people returned to the Arab political stages.

In January 2011, after Friday prayers, ordinary Arabs in Algeria, Bahrain, the Gaza Strip, Iraq, Yemen, Morocco, Oman, and Syria started to organize the so-called "Days of Rage" - or, popular demonstrations against their governments. In early March, 16 out of the 22 member states of the Arab League experienced different kinds of political unrest ${ }^{6}$. On January 14, 2011, following the mass protests in the country, Tunisian president Zine El Abidine Ben Ali, who had ruled the country for 23 years, was forced to flee. Encouraged by the success of the Tunisian protesters, Egyptians forced President Hosni Mubarak, who had been in power for nearly 30 years, to resign.

\footnotetext{
${ }^{3}$ Bouazizi died at a hospital on January 4, 2011.

${ }^{4}$ See: Ryan Y., "How Tunisia’s revolution began”, Al Jazeera English, 2601 2011, http://english.aljazeera.net/ indepth/features/2011/01/2011126121815985483.html, 03042011.

5 Corm G., "Is this an Arab spring?", Le Monde Diplomatique, 0604 2011, http://mondediplo. com/2011/04/02arabspring, 24052011.

${ }^{6}$ Fakhro E., Hokayem E., ,Waking the Arabs“, Survival, 53(2), April-May 2011, p. 22.
} 
Other dictators in the Middle East were also frightened. Yet, not all of them were forced to end their rule in a way similar to Ben Ali and Mubarak. Political leaders in Iraq, Jordan, Morocco and Oman had no major difficulties in dealing with minor disturbances in their respective countries. Frightened by the Arab uprisings, the ruling Saudi clan also managed to stabilize the situation in the country, at least for a short time. As a means of defense against the protesters, the Saudis used oil dollars, Wahhabi ideology and medieval punishments based on the interpretation of Sharia Law in order to maintain stability ${ }^{7}$. As the uprisings accelerated, the Saudis quickly allocated tens of billions of dollars on housing, unemployment and medical care ${ }^{8}$.

At first, the uprisings in the region were organized by ordinary civilians. Demonstrations usually proceeded peacefully. But this was not always the case. In some countries demonstrations against autocratic rulers turned into violent clashes between protesters and security forces loyal to the respective regimes. In the middle of February, Muammar Gaddafi, who had ruled Libya for more than 40 years, chose not to follow the pattern that was set by Ben Ali and Mubarak (i.e., to relinquish power peacefully). The Libyan dictator decided to get rid of the protesters by force. This decision brought civil war to Libya. Gaddafi's pattern was followed by Syrian dictator Bashir al-Assad, whose clan has ruled Syria for 40 years. He set army tanks against mainly peaceful protesters. The violent reaction by Gaddafi and Assad might have been influenced by the success achieved by Bahrain's ruling elite, which consists mainly of Sunnis, in crushing local protesters, who were mainly Shiites.

It is worth noting that the Arab uprisings started to stall in May. Middle Eastern kings, emirs and sultans had begun a quite successful counterattack. Their goal was to prevent political changes similar to those that had happened in Tunisia and Egypt. Besides, the Arab uprisings also started to stall because of the fatigue felt by the protesters. One can notice that protesters more often intend to achieve political changes by violent means. The use of violence is becoming an almost inseparable companion of the new political protests.

It is also worth mentioning that the Arab uprisings had no clear leaders. Most of the uprisings started without any central authority or coherent policy coordination. In many cases, demonstrations against dictators started even without participation by the traditional opposition groups?

\footnotetext{
7 Malik H., "Is It the Arab Spring?", USA: Johns Hopkins University, 3003 2011, , http://www.sais-jhu.edu/ bin/k/i/Is_It_The_Arab_Spring_30-3-11.pdf, 15042011.

${ }^{8}$ Joshi S., „Reflections on the Arab Revolutions: Order, Democracy and Western Policy“, The RUSI Journal, 156(2), April/May 2011, p. 64.

9 Cheterian V., "The Arab Revolt: Roots and Perspectives", GCSP Policy Paper $n^{\circ} 11$, February 2011, http:// www.gcsp.ch/content/download/4739/45272/download, 20042011.
} 
Social networking services like Facebook and Twitter played an important role at the beginning of the uprisings. They had a major impact on the intensity and spread of the uprisings in the region. But the impact of Facebook and Twitter on the Arab uprisings should not be overestimated. A significant role in the uprisings was played by information transmitted via mobile phones ${ }^{10}$ and satellite television channels, such as alJazeera and al-Arabiya. It should be noted that the new technologies often proved to be a double-edged sword during the uprisings. Autocratic regimes managed to use mobile phones and Facebook against the protesters as identification and tracking tools.

It is difficult to analyze the Arab uprisings without addressing the protesters themselves. Who are they? Who dared to revolt against the dictators ruling Middle Eastern countries for decades? According to the dictators, their enemies were criminals, fundamentalists, extremists and terrorists. According to experts analyzing the Arab uprisings, the rebels were youth, unemployed people, ordinary workers, trade unionists, sympathizers of Western liberal values, representatives of the middle-class, artists, intellectuals, feminists, farmers, and al-Qaeda linked terrorists. In fact, the rebels are a varied audience. Take for example the Libyan Transitional National Council: it consists of religious conservatives, liberals and social democrats ${ }^{11}$. In every country each protest movement has its unique core group. In Egypt the core group is comprised of tech-savvy youth; in Bahrain it is local Shiites dissatisfied with the Sunni ruling elite; in Syria it is local Sunni dissatisfied with the ruling of Alawis. Mika Aaltola and Timo Behr describe all the protesters as representatives of a generation raised under squalid conditions and nurtured on a diet of religious radicalism and totalitarianism ${ }^{12}$.

In one sentence it can be said that the Arab uprisings started due to countless numbers of long-term and short-term social, economic, political and religious factors. Experts analyzing the Arab uprisings highlight various causes. Among the many causes that led to the uprisings researchers (Aaltola, Behr, Cheterian, Johnstone, Mazo and others) mention the growing economic inequality, generational change, global financial and economic crisis, corruption, lack of good governance, failure of political leaders to meet rising expectations of people, political repression, rapid population growth, high unemployment, low wages, rapid increase of prices for food and essential goods, and climate change.

\footnotetext{
${ }^{10}$ Less than a quarter of Egyptians has internet access. Almost $80 \%$ of Egypt's population own mobile phones. See: Sharekh A., „Reform and Rebirth in the Middle East“, Survival, 53(2), April-May 2011, p. 56-57. See also: Swenson, Brynnar, "The Human Network: Social Media and the Limits of Politics," Baltic Journal of Law \& Politics 4:2 (2011): 102-124.

${ }^{11}$ Genugten S., „Libya after Gadhafi“, Survival, 53(3), June-July 2011, p. 62.

${ }^{12}$ Aaltola M., Behr T., The Arab Uprising: Causes, Prospects and Implications, The Finish Institute of International Affairs Briefing Paper 76, March 2011, www.fiia.fi/assets/publications/bp76.pdf, 02052011.
} 
It is worth noting that problems specific to the Middle East region were well-known long before. In 2002, the UN Arab Human Development Report stated that Arab countries have to deal with many challenges, such as poverty, food shortages, uneven economic growth, water shortages, the negative consequences of climate change, gender inequality, restrictions of political freedoms and the negative consequences of wars ${ }^{13}$. The Report points out that Middle Eastern governments have to strengthen the rule of law, to adhere to the principle of separation of powers, and to seek more active political participation by their citizens.

Actually, common and specific causes that led to the Arab uprisings in the Middle East can be pointed out. One proof that the uprisings had much in common was the rapid spread of protests across the whole region. All countries that have to deal with political unrest have similar features. The average Arab world population is generally young (See Table 1). Among Arab youth unemployment is usually high ${ }^{14}$. In addition, many young Arabs before the uprisings saw no chances to improve their living conditions in the future. According to Aaltola and Behr, the main common causes of the Arab uprisings are three deficits, (i.e. an economic deficit, a political deficit, and a dignity deficit ${ }^{15}$ ). In this case a deficit of dignity means a lack of respect from political leaders to ordinary citizens and also ambivalence among Arab governments in the international arena. Emmanuel Todd argues that the three main common causes of the Arab uprisings are the rapid increase in literacy, particularly among women; a falling birth-rate ${ }^{16}$; and thirdly, a significant decline in the widespread custom of endogamy, or marriage between first cousins ${ }^{17}$.

Of course, every uprising could be analyzed as a unique process with a special set of causes at its genesis. Such an analysis is easy to justify. The so-called Arab bloc is not homogeneous even if it is often seen as such. Arab countries are different according to various criteria (See Table 1). Some of them are rich (Bah-

\footnotetext{
${ }^{13}$ See further: United Nations Development Programme, Arab Human Development Report 2002, New York: UNDP Regional Bureau for Arab States, 2002, http://www.arab-hdr.org/publications/other/ahdr/ahdr2002e. pdf, 14112010 .

${ }^{14}$ It is estimated that within a decade Arab countries need to create 51 million new positions to accommodate young people seeking jobs. See: Cheterian V., "The Arab Revolt: Roots and Perspectives”, GCSP Policy Paper $n^{\circ} 11$, February 2011, http:// www.gcsp.ch/content/download/4739/45272/download, 20042011.

${ }^{15}$ Aaltola M., Behr T., The Arab Uprising: Causes, Prospects and Implications, The Finish Institute of International Affairs Briefing Paper 76, March 2011, www.fiia.fi/assets/publications/bp76.pdf, 02052011.

${ }^{16}$ The birth rate has fallen by half in the Arab world in just one generation, from 7.5 children per woman in 1975 to 3.5 in 2005. See: Leick R., "A Look at the Root Causes of the Arab Revolution: Rising Literacy and a Shrinking Birth Rate - Spiegel Interview with French social scientist Emmanuel Todd”, Spiegel Online International, 2005 2011, http://www.spiegel.de/international/world/0,1518,763537,00.html, 22052011. ${ }^{17}$ Leick R., "A Look at the Root Causes of the Arab Revolution: Rising Literacy and a Shrinking Birth Rate Spiegel Interview with French social scientist Emmanuel Todd”, Spiegel Online International, 2005 2011, http:// www.spiegel.de/international/world/0,1518,763537,00.html, 22052011.
} 
rain, Saudi Arabia and Libya), while others are very poor (Yemen). The citizens of some Arab countries have relatively wide political rights and freedoms (Iraq, Morocco and Jordan), while for others (Saudi Arabia, Libya and Syria) it is very limited. In some Arab countries corruption is more widespread (Iraq, Yemen and Libya), while in the others it is less so (Bahrain and Jordan).

Table 1. Features of some Middle Eastern countries

\begin{tabular}{|c|c|c|c|c|c|}
\hline Country & Democracy ${ }^{*}$ & $\begin{array}{l}\text { GNI per } \\
\text { capita** }^{* *}\end{array}$ & Corruption $^{\star \star *}$ & Unemployment $^{\star \star * *}$ & $\begin{array}{l}\text { Median } \\
\text { age }^{\star * \star * * *}\end{array}$ \\
\hline Algeria & 125 & 8120 & 105 & 10,0 & 27,6 \\
\hline Bahrain & 122 & 24710 & 48 & 15,0 & 30,9 \\
\hline Egypt & 138 & 6160 & 98 & 9,0 & 24,3 \\
\hline Iraq & 111 & 3350 & 175 & 15,3 & 20,9 \\
\hline Yemen & 146 & 2350 & 146 & 35,0 & 18,1 \\
\hline Jordan & 117 & 5810 & 50 & 12,5 & 22,1 \\
\hline Libya & 158 & 16740 & 146 & 30,0 & 24,5 \\
\hline Morocco & 116 & 4620 & 85 & 9,1 & 26,9 \\
\hline Saudi Arabia & 160 & 22540 & 50 & 10,8 & 25,3 \\
\hline Syria & 152 & 5150 & 127 & 8,3 & 21,9 \\
\hline Tunisia & 144 & 8130 & 59 & 13,0 & 30,0 \\
\hline
\end{tabular}

Of all causes that led to the Arab uprisings it is worth focusing on climate change. The Middle East region is especially sensitive to food prices and these are directly affected by climate change. The Middle East region imports more food per capita than any other ${ }^{18}$. The protests in early January in Algeria and Tunisia were caused by rising prices in sugar, milk and bread. As suggested by analysts Sarah Johnstone and Jeffrey Mazo, climate change may not have caused the Arab Spring, but it did make it come earlier.

The outcome of the Arab uprisings is difficult to predict. Every uprising is a process that has its specific features. In addition, the Arab uprisings are still ongoing. One should keep in mind that an uprising, as a process, has at least two players involved. Sometimes it is difficult to understand and explain the actions

\footnotetext{
* Higher number = less democracy. Source: The Economist Intelligence Unit, Democracy Index 2010, http:// graphics.eiu.com/PDF/Democracy_Index_2010_web.pdf, 30082011.

** Source: The World Bank, GNI per capita, http://data.worldbank.org/indicator/NY.GNP.PCAP.PP.CD, 30082011.

*** Higher number = greater corruption. Source: Transparency International, Corruption Perceptions Index 2010 Results, http://www.transparency.org/policy_research/surveys_indices/cpi/2010/results, 30082011.

**** Source: Central Intelligence Agency, The World Factbook, https:/www.cia.gov/library/publications/theworld-factbook/, 30082011.

***** Source: Central Intelligence Agency, The World Factbook, https:/www.cia.gov/library/publications/ the-world-factbook/, 30082011.

${ }^{18}$ Johnstone S., Mazo J., „Global Warming and the Arab Spring“, Survival, 53(2), April-May 2011, p. 13.
} 
of these players. However, it is these actions that determine the ultimate outcome of the uprising. The real consequences of the Arab uprisings are likely to be seen only after a few decades. So far, it is clear that strategically important changes are taking place in the Middle East. These changes affect the political and geopolitical situation in the region.

At first glance, the Arab uprisings might seem reminiscent of the twentiethcentury waves of democratization that rolled over Asia, Latin America, Europe and Africa. In fact, many Arab protesters are technology-savvy representatives of the middle class who seek more political rights and freedoms. But it is far too early to claim that the Arab uprisings have brought more democracy to the Middle East. A large part of the Arab protesters are not enthusiastic supporters of Western values, nor are they fans of the international political system created by the Western powers.

Regarding prospects for greater democratization one needs to answer the question - what are the goals that Arab protesters want to achieve? Unfortunately, in most cases there is no answer to this question. The Arab protesters who took to the streets held very different political, economic and social grievances. Some of the protesters wanted to have more democracy and a more liberal regime, while others sought significant economic reforms or social change. In addition, there were those who wanted all of these things mentioned above as well as those who simply wanted change for the sake of change. What are the goals of the protesters in Libya or Syria? Do they fight for more democracy? Today it is hard to give definitive answers.

Many regimes in the Arab countries that were caught by the wave of massive protests still manage to resist demands for change. Even the victories achieved by the protesters in Tunisia and Egypt do not mean that these countries will enjoy more democracy. Changing the political leader does not mean that a deep transformation of the whole regime will follow. The overthrow of the dictator is merely the first step towards greater political changes. Currently, the main actors in the Tunisian and Egyptian political arenas are military men. Generals with political power in their hands are rarely liberals and supporters of a democratic form of government. Weeks after the ouster of Mubarak, the Egyptian army employed arbitrary detention and torture ${ }^{19}$. At the end of March the new political rulers of Egypt passed a law banning all demonstrations.

After the uprisings one could say that there is even less democracy in the Middle East. Member states of the Gulf Cooperation Council (Bahrain, UAE, Qatar, Kuwait, Oman, and Saudi Arabia) are already trying to tighten their control over their societies. In the major cities of these countries new surveillance cameras

\footnotetext{
${ }^{19}$ Joshi S., „Reflections on the Arab Revolutions: Order, Democracy and Western Policy“, The RUSI Journal, 156(2), April/May 2011, p. 64.
} 
are installed. Governments are encouraging citizens to notify police about every person who dares to criticize the political leadership or the regime ${ }^{20}$. Moreover, many Middle Eastern governments demonstrate a strong desire to pass stricter controls over internet users and social networking services.

There are at least three scenarios for the uprisings in the Middle East to proceed. One may be called the Tiananmen Square scenario. This scenario is about toppling the protest movement by force. This scenario was chosen by autocratic rulers of Bahrain, Libya, Syria, and in a sense Yemen. This scenario might lead to a civil war. The end of this scenario might be the restoration of a status quo favorable to dictators or deep political changes in the political regime after a victory is achieved by the rebels. A second possible scenario is cosmetic reforms directed from above. According to this scenario, the autocratic rulers will make small concessions, but try to hold onto power. It seems that the political leaders of Algeria, Jordan, Morocco, Oman and Saudi Arabia have chosen this scenario. A third scenario could be called the Turkish approach. Many experts of the Arab uprisings agree that Middle Eastern protesters would like to have a political regime similar to the Turkish one. This means that they want to have a political system with democratic elements. However, they also want to see a strong military with generals as the main decision makers for all strategically important decisions. There is a high probability that Tunisia and Egypt will take the Turkish approach.

In summing up this section, we can say that the various Arab uprisings have similarities to each other, but they also have important differences. The consequences of the uprisings are hard to predict. The most important consequences of the uprisings for the Middle East region will become visible only after several decades. The victories achieved by the protesters in Tunisia and Egypt do not mean that substantial political changes and more democracy will follow. The new political rulers that emerged during the uprisings can be overthrown themselves if longstanding political, economic and social problems are not solved.

\section{The Effect of the Arab Uprisings on Western Security Interests}

It makes sense to start this chapter with a brief overview of Western (NATO and EU) interests in the Middle East region. According to Samuel P. Huntington, the most important interest of the West is to maintain Western predominance in

\footnotetext{
${ }^{20}$ Smoltczyk A., Windfuhr V., "Arab Spring Stalls", Spiegel Online International, 1805 2011, http://www. spiegel.de/international/world/0,1518,762861,00.html, 19052011.
} 
the world ${ }^{21}$. This is also relevant in the case of the Middle East. In order to maintain its predominance in the world, the West has to control situations in other regions, including the Middle East, so that they will not pose a threat to Western security. Put simply, no Western political leader would like to see history repeat itself in a way similar to the siege of Vienna by the Ottoman army in the sixteenth century.

Of course, Huntington's theory must be viewed critically. The theory of a clash of civilizations is unable to explain properly the Arab uprisings. However, intentions of the Western powers to manage events and processes in the Middle East are a "public secret": the British ousted Egyptian premier Ali Mahir in 1942; the CIA was behind coups in Syria in 1949; British and American intelligence services took part in a coup against Iranian prime minister Mohammad Mosaddegh in 1953; British and French military forces took part in the Tripartite Aggression against Egypt in 1956 $6^{22}$. In addition, it is worth recalling the fact that from the fall of the Ottoman empire until World War II the Middle East was mainly in full control of the major European countries.

Western security is closely linked to the Middle East for a variety of reasons. One is the geographical proximity of the Middle East to the West. Western countries in Southern Europe have common borders with Middle Eastern countries. Since ancient times the West has been interested in the Middle East for economic reasons and remains interested in the Middle East today because of the region's energy resources. Arab oil was, and remains, of vital importance for Western economic and commercial wellbeing ${ }^{23}$. After the Second World War wealthy Middle Eastern states were desired by Westerners as buyers of their arms. The Middle East also attracts the attention of Western political leaders because of the large flow of immigrants from the Middle East relocating to EU member states each year. Over the past decade the Middle East attracted huge Western attention because of socalled War on Terror. The region is the geographic area of origin for many terrorist groups targeting Western interests worldwide. In addition, the West is interested in spreading Western political and economic values in Middle Eastern countries ${ }^{24}$. The U.S., the most powerful Western country, has a very special interest in the Middle East. Washington is committed to maintaining the security and prosperity of Israel ${ }^{25}$. Additionally, one should not forget that during the Cold War the Middle East region was a geopolitically important field of struggle between the two superpowers.

\footnotetext{
${ }^{21}$ Huntington S. P., „The Clash of Civilizations?“, Foreign Affairs, 72(3), 1993, p. 40.

${ }^{22}$ Halliday F., The Middle East in International Relations: Power, Politics and Ideology, US: Cambridge University Press, 2005, p. 70.

${ }^{23}$ Milton-Edwards B., Hinchcliffe P., Conflicts in the Middle East since 1945, Third edition, UK: Routledge, 2008 , p. 38.

${ }^{24}$ Huntington S. P., „The Clash of Civilizations?“, Foreign Affairs, 72(3), 1993, p. 40.

${ }^{25}$ Milton-Edwards B., Hinchcliffe P., Conflicts in the Middle East since 1945, Third edition, UK: Routledge, 2008, p. 38-39.
} 
In the second half of the twentieth century and in the beginning of the twenty-first century the security interests of the West in the Middle East were protected by Israel, by American soldiers based nearby or in the region itself, and by autocratic Middle Eastern rulers. The West needed Middle Eastern dictators because they were useful. Western countries could use them for implementing their security interests and at the same time to stay less visible as political or military players in the Middle East. For the local population and other interested parties it was problematic to blame the West, because they subtly manipulated local autocratic leaders. So, it is not surprising that before the Arab uprisings Western leaders had closely collaborated with the autocratic regimes for decades ${ }^{26}$. According to Joshi, the situation was even more complicated than it appears at first glance. The West always had to deal with a trilemma in the Middle East. They had to balance between the desires to foster democracy, maintain stability yet still encourage pro-Western foreign policy among the nations of the region ${ }^{27}$. However, even Joshi has to acknowledge that before the Arab uprisings the West always preferred stability and pro-Western foreign policy over democracy.

In the twentieth century the West had no interest in democratization of the Middle East region. Rashid Khalid claims that the spread of democracy in the Middle East was not a big issue for the West. On the contrary - various manifestations of democratic governance in Middle Eastern countries were often deliberately suppressed by Western powers ${ }^{28}$. For the West it was much easier to deal with easily manipulated and predictable autocratic leaders than with democratic ones, who had to take into account public opinion.

In most cases Western strategists were not interested in the domestic politics of the Arab countries. For the sake of stability in the Middle East, it was not a problem for them to close their eyes to the shortcomings of the autocratic regimes. Among these shortcomings were a thriving corruption in ruling circles, various violations of human and civil rights, and the omnipotence of local security and intelligence services. If representatives of civil society in the West had doubts about the ethics of their governments' cooperation with Middle Eastern dictatorships it was easy to justify such cooperation. Arguments about Islamist threats and the free flow of oil were used by Western governments in such cases ${ }^{29}$.

\footnotetext{
${ }^{26}$ Cheterian V., "The Arab Revolt: Roots and Perspectives", GCSP Policy Paper nº11, February 2011, http:// www.gcsp.ch/content/download/4739/45272/download, 20042011.

27 Joshi S., „Reflections on the Arab Revolutions: Order, Democracy and Western Policy“, The RUSI Journal, 156(2), April/May 2011, p. 60.

${ }^{28}$ Rashid Khalidi, „The Arab Spring“, The Nation, 292(12), 2103 2011, p. 8.

${ }^{29}$ Joshi S., „Reflections on the Arab Revolutions: Order, Democracy and Western Policy“, The RUSI Journal, 156(2), April/May 2011, p. 62.
} 
The security interests of the West and the decades-long cooperation with the Middle Eastern autocratic political leaders also explain why many Western political leaders in January 2011 seemed confused. In fact, the leaders of the Western powers even delayed their support for Arab protesters that openly stated that they seek to create a Western-type democracy. Western strategists needed time to rethink the basics in the relationship with the Middle Eastern countries. They had to find an answer to the question: what will happen with the Western security interests if easily manipulated and predictable dictators are replaced with new and unpredictable political actors?

Thus, the silence of officials in Washington, London, Paris and Brussels at the beginning of the uprisings is easy to understand. The fact is that many Middle Eastern dictators had bank accounts in the Western countries. French political leaders maintained close ties with friends of Tunisian dictator Ben Ali. Michele Alliot-Marie, who was the French foreign minister from November 2010 till February 2011, took trips on a private jet belonging to a close associate of Ben Ali. As riots in Tunisia were just starting she offered the support of French security forces to Ben Ali to stem the demonstrations ${ }^{30}$. French Prime Minister Francois Fillon enjoyed free holidays on the Nile as Mubarak's guest ${ }^{31}$. Before the Arab uprisings France benefited from the sale of weaponry to Libya.

For its part, Great Britain saw no problem in selling weaponry to autocratic Gulf regimes before the uprisings. British Prime Minister David Cameron promoted British arms sales on his official visit to the Gulf region in February $2011^{32}$. The U.S. closely cooperated with Mubarak's regime on various political, military and economic issues for decades. For many years before the uprisings the U.S. gave Egypt military aid worth approximately 1.5 billion dollars every year. Two weeks before the ouster of Mubarak, U.S. Vice President Joe Biden called the Egyptian president an ally of America and a responsible political leader. Biden even suggested that Mubarak not be referred to as a dictator ${ }^{33}$.

The U.S. and Egypt especially strengthened their cooperation on security issues after the September 11 attacks. The Egyptian secret services cooperated with their American colleagues in the illegal kidnappings and torture of suspected

\footnotetext{
${ }^{30}$ Joshi S., „Reflections on the Arab Revolutions: Order, Democracy and Western Policy“, The RUSI Journal, 156(2), April/May 2011, p. 61.

${ }^{31}$ Cheterian V., "The Arab Revolt: Roots and Perspectives", GCSP Policy Paper $n^{\circ} 11$, February 2011, http:// www.gcsp.ch/content/download/4739/45272/download, 20042011.

32 Joshi S., „Reflections on the Arab Revolutions: Order, Democracy and Western Policy“, The RUSI Journal, 156(2), April/May 2011, p. 61.

33 The Christian Science Monitor, “Joe Biden says Egypt's Mubarak no dictator, he shouldn't step down...”, USA: The Christian Science Monitor, 2701 2011, http://www.csmonitor.com/World/Backchannels/2011/0127/Joe-Biden-says-Egypt-s-Mubarak-no-dictator-he-shouldn-t-step-down, 05062011.
} 
terrorists ${ }^{34}$. In addition, Egypt played an important role in the regional alliance system serving American foreign policy interests. Mubarak's Egypt was a member of the anti-Iranian regional bloc created by Washington. During Mubarak's presidency Egypt developed a good relationship with Israel, a U.S. proxy in the region. Actually, many pro-American Middle Eastern dictators were closely following America's position towards Egypt during the uprising against Mubarak. The hasty and ill-considered reaction of Washington to the events in Egypt could easily have destroyed the whole pro-American alliance system in the Middle East, which was created during the decades of hard diplomatic work ${ }^{35}$.

The U.S. reaction to the Arab uprisings is the so-called Obama doctrine. The search for such doctrine started long before the Arab uprising. Origins of the doctrine can be traced back to Obama's presidential election campaign, which officially was launched in February 2007. The basics of this doctrine can be found in Obama's Cairo speech on the June 4, 2009. This speech was an attempt to reset the U.S. relationship with various Muslim communities. In essence, the Obama doctrine is an attempt to change the doctrine formed by former U.S. President George W. Bush. One of the main ideas in the Bush doctrine was to hasten the spread of democracy in the Middle East. It is often associated with the term 'regime change'. American military superiority was an integral part of the Bush doctrine. This doctrine was widely unpopular in the Arab world.

President Obama wanted to distance himself from Bush's legacy with the new doctrine. In his statements related to the Arab uprisings Obama carefully avoided the use of the term 'regime change'. In his speech on the Arab uprisings on the May 9, 2011, Obama stated that the U.S. will follow three principles. The first principle - the U.S. opposes the use of violence and repression against the people of the Middle East region; second - the U.S. supports a set of universal rights (these rights include: free speech; the freedom of peaceful assembly; freedom of religion; equality for men and women under the rule of law; and the right to choose leaders); and third - the U.S. supports political and economic reforms in the Middle East that can meet the legitimate aspirations of ordinary people throughout the region ${ }^{36}$. The U.S. reaction to the Arab uprisings demonstrated that Obama's administration first of all would like to get international support and approval for any military actions and only then resort to force. According

\footnotetext{
${ }^{34}$ Cheterian V., "The Arab Revolt: Roots and Perspectives", GCSP Policy Paper $n^{\circ} 11$, February 2011, http:// www.gcsp.ch/content/download/4739/45272/download, 20042011.

${ }^{35}$ Lynch M., „America and Egypt After the Uprisings“, Survival, 53(2), April-May 2011, p. 35.

${ }^{36}$ Obama B., "A Moment of Opportunity", Washington: The White House, 1905 2011. http://www. whitehouse.gov/the-press-office/2011/05/19/remarks-president-barack-obama-prepared-delivery-momentopportunity, 25052011.
} 
to Bruce Jones, the Obama administration emphasized diplomacy and political engagement with its opponents ${ }^{37}$. Marc Lynch claimed that Obama's handling of the Egyptian case has established a template for American treatment of other cases of domestic upheaval in the Middle East ${ }^{38}$.

However, the Bahrainian uprising, which became sort of a test of the Obama doctrine, demonstrated that words remain words, and interests - interests. The Bahrainian ruling elite, with the assistance of Saudi Arabia and the UAE security forces, crushed local protesters. At the time of crackdown the Fifth Fleet of the U.S. Navy, which is headquartered in Bahrain, played the role of indifferent observer. The same indifference on the side of the U.S. can be seen in the case of the Syrian uprising, which Assad is also trying to suppress by force. Habib Malik therefore concludes that the repressive and nasty Assad regime is seen in Washington as a lesser evil when compared to open-ended chaos or a Sunni takeover $^{39}$.

The best case that indicates Western support for rebels over dictators might be the Libyan uprising. In this case the Western countries directly intervened into the ongoing armed uprising on the side of the rebels. It was this initiative, taken by France, Great Britain and the U.S., that resulted in UN Security Council resolution 1973. This resolution opened the way for Western powers to intervene with military means into the Libyan civil war. Resolution 1973 demanded Gaddafi to stop attacks on protesters, strengthened the arms embargo, authorized the international community to establish a no-fly zone, allowed the members of the international community to use all means necessary short of foreign occupation to protect Libyan civilians ${ }^{40}$. On March 19, 2011, French, American, and British military forces started attacks against Gaddafi's soldiers posing a threat to Libyan civilians. On March 27, NATO took control of the international military operation, aimed at implementing UN SC resolution 1973.

The military operation in Libya is a third Western military intervention in recent years in a Muslim country. Of course the U.S. does its best to avoid the comparison of the Libyan operation to the American operations in Afghanistan and Iraq. At the earliest opportunity the U.S. gave the leadership of the mission to NATO. Before that Americans were actively searching for European country

\footnotetext{
${ }^{37}$ Jones B. D., „Libya and the Responsibilities of Power“, Survival, 53(3), June-July 2011, p. 58.

${ }^{38}$ Lynch M., „America and Egypt after the Uprisings“, Survival, 53(2), April-May 2011, p. 32.

${ }^{39}$ Malik H., "Is It the Arab Spring?”, USA: Johns Hopkins University, 3003 2011, http://www.sais-jhu.edu/ bin/k/i/Is_It_The_Arab_Spring_30-3-11.pdf, 15042011.

${ }^{40}$ United Nations Security Council, "Resolution 1973 (2011)", New York: United Nations, 1703 2011, http://daccess-dds-ny.un.org/doc/UNDOC/GEN/N11/268/39/PDF/N1126839.pdf?OpenElement, 2203 2011.
} 
to take the lead. Because of lessons learned in Afghanistan and Iraq, political leaders of the Western powers immediately rejected idea of the land-based military intervention in Libya. Actually, some influential members of NATO like Germany and Turkey at the beginning of intervention had many doubts about the necessity of the military operation in Libya under the NATO's leadership.

Western military involvement in the Libyan uprising is sort of a risky adventure. It gives the impression that the West supports the rebels eager for reforms in Libya and other Middle Eastern countries. However, Western political leaders sometimes seem confused about their own decision to use military force in support of the Libyan protesters ${ }^{41}$. There is no doubt that Western powers remember quite well the not very successful democratization experiments in Afghanistan and Iraq. In agreement with Saskia van Genugten, it can be stated that those who are involved in nation-building and state-building in Libya really are building on sand ${ }^{42}$. It is a similar notion of state-building on sand that has already happened in Afghanistan and Iraq.

There is no clarity about which way Libya will turn when the Libyan rebels achieve victory over Gaddafi and his supporters. Adm. James Stavridis says that elements of Al Qaeda and Hizbollah "are flickering" among the Libyan rebels fighting against Gaddafi ${ }^{43}$. So, there are more questions than answers related to the Libyan uprising and its result. Perhaps, the very fact that the consequences of the uprisings remain unknown explains the caution that Western powers have from intervening in other uprisings on the side of the rebels.

Almost all experts analyzing the Arab uprisings point out that the role played by the Western countries in uprisings is very important. However, the capabilities of the Western powers to determine the end state of the uprisings are limited. The West does not possess the levers required to keep the democratization process in the Middle East under control ${ }^{44}$. Because of that they are afraid of encouraging further democratization in the Middle East.

What will be the impact of the Arab uprisings on Western security interests? It is likely that the most important western security interests will not change. Most likely, the implementation of the Western security interests in

\footnotetext{
${ }^{41}$ It is worth to noticing that the West is not united on the Libyan case. Germany had no enthusiasm about Western military involvement in Libya and abstained during the vote in the Security Council of Resolution 1973.

${ }^{42}$ Genugten S., „Libya after Gadhafi“, Survival, 53(3), June-July 2011, p. 72.

${ }^{43}$ CNN, “'Flickers' of al Qaeda in Libyan opposition, U.S. NATO leader says", US: Turner Broadcasting System Inc., 2903 2011, http://articles.cnn.com/2011-03-29/us/libya.opposition.analysis_1_james-stavridismoammar-gadhafi-al-qaeda-or-one?_s=PM:US, 07072011.

${ }^{44}$ Joshi S., „Reflections on the Arab Revolutions: Order, Democracy and Western Policy“, The RUSI Journal, 156(2), April/May 2011, p. 62.
} 
the Middle East will remain in the hands of those who are supporters of the principles of realpolitik. So, one may ask - what will change? It is already clear that, because of the Arab uprisings, the West will have to work much harder in trying to meet its interests. Ordinary citizens of the Western countries may more strongly demand that their political leaders restrict cooperation with autocratic regimes in the Middle Eastern region. The image of Arabs in the eyes of many Westerners after the uprisings will change. According to Joshi, it is the Western public sphere that is likely to be the most affected by revolutionary change in the Middle Eastern countries ${ }^{45}$. Before the uprisings many in the West saw Arabs as bearded radicals who stand against the process of globalization. Now, this image may change. The uprisings demonstrated that many young Arabs are tech-savvy and do not want to live in a regime similar to a theocratic Iran.

The Arab uprisings will create more difficulties for the West to defend its interests, because many ordinary Arabs are keen to review their relationship with the Western countries. Arab countries, where protesters acquired political power, may seek to change the course of pro-Western foreign policy towards a more independent one. Mubarak's pro-Western foreign policy was one of the reasons why Egyptians took to the streets. Protesters in Egypt were less than happy to see their country on the international political arena acting like an American puppy $^{46}$. It is obvious that in the future Middle Eastern political leaders will pay attention to that fact. Many protesters in the Middle East simply do not trust the West, because for decades Western countries cared only about their own interests and supported dictators. That is why Arab protesters may seek to review the relationship with the West, which in turn may signify the end of Western hegemony in the Middle East ${ }^{47}$. In addition, the Arab uprisings may contribute to a more decentralized, and truly multipolar world order.

It is likely that after the uprising Egypt will cooperate less with the traditional Western proxy in the region- Israel. This will affect bilateral cooperation in political, economic and military fields. Still, the Israel-Egypt peace treaty should not be broken. In general, after the uprisings many Middle Eastern countries may express stronger demands towards the West to solve the Israeli-Palestinian conflict. Actually, a solution to this decades-long conflict could benefit both sides - the West and the Middle East region. Arab Human Development Report 2002 states

\footnotetext{
${ }^{45}$ Joshi S., „Reflections on the Arab Revolutions: Order, Democracy and Western Policy“, The RUSI Journal, 156(2), April/May 2011, p. 61.

${ }^{46}$ Aaltola M., Behr T., The Arab Uprising: Causes, Prospects and Implications, The Finish Institute of International Affairs Briefing Paper 76, March 2011, www.fiia.fi/assets/publications/bp76.pdf, 02052011. ${ }^{47}$ Aaltola M., Behr T., The Arab Uprising: Causes, Prospects and Implications, The Finish Institute of International Affairs Briefing Paper 76, March 2011, www.fiia.fi/assets/publications/bp76.pdf, 02052011.
} 
that Israel's illegal occupation of Arab lands is one of the most pervasive obstacles to security and progress in the region geographically, temporally and developmentally ${ }^{48}$.

Cooperation with Arab countries in the fight against terrorism after the uprisings will be more complicated for the West. Of course, cooperation in this field has never been perfect. But since 2002 counter-terrorism cooperation with Arab countries was a clear priority for the Western governments. Western countries invested a lot to make the cooperation on counter-terrorism issues the most developed area of cooperation in the security field. Since the start of the War on Terror the West worked hard to strengthen the capabilities of the Middle Eastern security and intelligence services ${ }^{49}$. Many protesters in the Middle East hate local security and intelligence services, because of the important role they played in tracking and abusing peaceful dissenters. It is not surprising that the wrath of Egyptian protesters was directed at the SSIS (State Security Investigations Service). After the ouster of Mubarak new Egyptian political leaders were forced to announce the dissolution of the agency. During the Mubarak's rule the SSIS enjoyed close relations with the FBI and the CIA ${ }^{50}$. The SSIS even received suspected terrorists from the Americans for interrogation under the U.S. rendition program.

However, the Arab uprisings have shown that Al Qaeda, the widely feared terrorist group among Western countries, is a marginal organization. Al Qaeda and related jihadi groups are unable to affect the process of change in the Arab world ${ }^{51}$. Civilians in Tunisia and Egypt in a few weeks managed to achieve what Al Qaeda and associated groups could not reach in about two decades of armed struggle. According to Steven Simon, the Arab uprisings are a strategic defeat of violent jihadism ${ }^{52}$.

There is no doubt, that during the uprisings Al Qaeda and related jihadi groups may try to take advantage of the poor security situation in Yemen, Libya and other weak Middle Eastern countries. However, Al Qaeda's ability to mo-

\footnotetext{
${ }^{48}$ United Nations Development Programme, Arab Human Development Report 2002, New York: UNDP Regional Bureau for Arab States, 2002, http://www.arab-hdr.org/publications/other/ahdr/ahdr2002e.pdf, 14 112010 .

${ }^{49}$ Fakhro E., Hokayem E., „Waking the Arabs“, Survival, 53(2), April-May 2011, p. 27.

${ }^{50}$ McGregor A., "Egypt’s Internal Security Service Collapses in a Storm of Charges and Revelations", Terrorism Monitor, 9(14), 0704 2011, http://www.jamestown.org/single/?no_cache=1\&tx_ttnews[swords ]=8fd5893941d69d0be3f378576261ae3e\&tx_ttnews[any_of_the_words]=arab\%20revolts\&tx_ttnews[tt_ news]=37766\&tx_ttnews[backPid]=7\&cHash=431c2da3af2798288fbd84570ee52266, 07062011.

${ }^{51}$ Fakhro E., Hokayem E., „Waking the Arabs“, Survival, 53(2), April-May 2011, p. 26.

52 Shane S., "As Regimes Fall in Arab World, Al Qaeda Sees History Fly By", The New York Times, 2702 2011, http://www.nytimes.com/2011/02/28/world/middleeast/28qaeda.html, 04052011.
} 
bilize the Arab masses was always very limited. Jihadi terrorist attacks against Muslim civilians and their apocalyptic visions never had the power to inspire the Arab masses ${ }^{53}$.

Some radical groups, which are sometimes classified as terrorist in the West, might be more influential after the uprisings. Many protesters at the beginning of the uprisings did not try to hide their sympathy for Hizbollah leader Hassan Nasrallah ${ }^{54}$. Some protesters in public expressed their support for Hamas in Palestine. It is very likely that after the uprisings many Islamist parties and movements such as the Muslim Brotherhood will become legal political players. But the West needs not to fear the legitimization of Islamists. Islamists are not jihadists. Active participation of Islamists in the political life of the Middle Eastern countries might help to strengthen democracy in the region ${ }^{55}$.

With regard to the impact of Arab uprisings on Western interests it is worth noting that over a long period the spread of democracy in the Middle East could be useful for the West. The political dialogue between the West and new more democratic Middle Eastern regimes might have a stronger basis and be mutually beneficial. This in its turn might help to solve various security challenges in a more efficient way. The problem is that for many Middle Eastern countries the road to democracy can be very long. In addition, many Arab countries may never reach the finish line - the establishment of truly democratic regimes. There are many historical examples of implantation of democracy outside the traditional boundaries of Western world that ended with contradictory results.

In general, the Arab uprisings, at least in the short term, do not promise anything positive for the West and its security interests. It is obvious that autocratic Arab leaders, who for decades were supported by the West, are no longer capable of ensuring stability in the region. However, new political forces that emerged during the uprisings are not familiar to the Western leaders, and are thus unpredictable. The abilities of the new Arab leaders to address deep-rooted political, economic and social problems are doubtful. This means that the new political players may also be unable to create the stability desired by the West. Cooperation with Arab countries in the fight against terrorism after the uprisings will become more complicated for the West. European countries already have to solve many problems created by the new flows of immigrants from the Middle East, who try to find shelter in Europe because of the political unrest at home.

\footnotetext{
${ }^{53}$ Fakhro E., Hokayem E., „Waking the Arabs“, Survival, 53(2), April-May 2011, p. 26.

${ }^{54}$ Aaltola M., Behr T., The Arab Uprising: Causes, Prospects and Implications, The Finish Institute of International Affairs Briefing Paper 76, March 2011, www.fiia.fi/assets/publications/bp76.pdf, 02052011.

${ }^{55}$ Hamid Sh., „Arab Islamist Parties: Losing on Purpose?“, Journal of Democracy, 22(1), January 2011, p. 68-80.
} 


\section{Arab Uprisings and Lithuanian Interests}

Since 2004 Lithuania belongs to such key Western organizations as NATO and the EU and Lithuania has the same security challenges as the other Western countries. Lithuanian politicians and security experts quite often discuss such threats as energy security, terrorism, cyber attacks, and climate change. It is no coincidence that all these threats are included in the new draft of the Lithuanian National Security Strategy ${ }^{56}$.

As it is equally affected by the process of globalization Lithuania cannot distance itself from security problems that are on the international political agenda. According to Gediminas Vitkus, in the age of globalization an individual nation's security is shared with other nations ${ }^{57}$. Nevertheless, like all countries, Lithuania has its own priorities while pursuing its security and foreign policy objectives. Furthermore, one should take into account that Lithuania is a relatively small, weak and young country ${ }^{58}$. Its human and material resources that can be used in implementing security and foreign policy goals are comparatively small.

Lithuanian security and foreign policy makers traditionally concentrate their attention on the neighboring countries - Russia, Belarus, Poland, Latvia and Estonia. In addition, Vilnius is more focused on the successor states of the former Soviet Union; of these, three receive particular focus - Georgia, Moldova and Ukraine. Obviously, high on the Lithuanian political agenda is cooperation with powerful Western countries. Of these the U.S. is the most important one. According to some Lithuanian security experts, Lithuania's membership in NATO is a favor granted by the U.S. ${ }^{59}$ In their view, Lithuanian membership in the EU can guarantee security only until the EU itself is protected by the U.S. military. It is worth noticing that after the presidential elections in May 2009, the new Lithuanian president, Dalia Grybauskaite, tried to refocus foreign policy and to put a stronger emphasis on relations with Brussels, Paris, and Berlin. However, at this time Lithuania's security is still dependent on the U.S.

It is worth to note that despite limited resources Lithuania takes part in military missions that are not high on the national security and foreign policy

\footnotetext{
${ }^{56}$ See: Lietuvos Respublikos Seimas, "Nutarimas dèl Lietuvos Respublikos Seimo nutarimo 'dèl Nacionalinio saugumo strategijos patvirtinimo' pakeitimo" (nutarimo projektas), 0107 2011, http://www3.lrs.lt/pls/inter3/ dokpaieska.showdoc_l?p_id=403085\&p_query=\&p_tr2=, 03082011.

${ }^{57}$ Vitkus G., „Integraciniai tarptautinio saugumo procesai versus jègų balansas“, Skaitiniai apie nacionalinį ir tarptautini sauguma, Vilnius: Atlanto sutarties Lietuvos bendrija, 2000, p. 17.

${ }^{58}$ Laurinavičius Č., Motieka E., Statkus N., Baltijos valstybiu geopolitikos bruožai: XX amžius, Vilnius: LII leidykla, 2005, p. 192.

${ }^{59}$ Laurinavičius Č., Motieka E., Statkus N., Baltijos valstybiu geopolitikos bruožai: XX amžius, Vilnius: LII leidykla, 2005, p. 192.
} 
priorities list and are more important for other Western countries. For instance, Lithuania takes part in the ISAF mission in Afghanistan, the NATO Training Mission in Iraq, and the EU "Atalanta" operation ${ }^{60}$. In 2005, Lithuania took the unique responsibility to lead the Provincial Reconstruction Team mission in the Ghor province of Afghanistan.

However, it can be said that Lithuania is clearly less interested in the Middle East region than in its real "Middle East" that is composed of Russia, Belarus, Georgia, Moldova and Ukraine. According to Egdunas Racius, who is a lecturer at the Institute of International Relations and Political Science, Lithuania does not have direct access to the Mediterranean Sea and the Arab states and because of that Lithuania does not have inherent interests in the Middle East ${ }^{61}$. In fact, Lithuania has no strong historical, political or economic ties with the Middle East region. In essence, the Middle East interests Lithuania as much as events in this region could affect the security of the U.S. (NATO) and the EU.

Of all the Middle Eastern Arab countries, Lithuania only has an embassy in Egypt, which is a popular destination point for Lithuanian tourists. In theory, the Lithuanian embassy in Egypt also has to defend Lithuanian interests in Jordan, Syria, Lebanon, Kuwait, UAE, Saudi Arabia and Qatar. In practice, the Lithuanian embassy in Egypt is unable to fulfill this task. The Lithuanian embassy in Cairo is staffed with only two diplomats ${ }^{62}$. By comparison, the Lithuanian embassy in Chisinau, Moldova, is tasked to take care of Lithuanian interests in only this one country and is staffed with three diplomats.

Lithuanian commercial ties with Middle Eastern countries are poor. Among the first two dozens of Lithuania's largest foreign trade partners there are no Arab countries $^{63}$. Examples of the bilateral military cooperation between Lithuania and the Middle Eastern countries are hard to find.

A lack of interests and limited diplomatic capabilities has not stopped Lithuanian political leaders as they have expressed their positions on the Arab uprisings. Lithuanian politicians had to say something about the Arab uprisings, for several

\footnotetext{
${ }^{60}$ Krašto apsaugos ministerija, 2303 2011, http://www.kam.lt/lt/tarptautinis_bendradarbiavimas/tarptautines_operacijos/kodel_dalyvaujame.html, 08082011.

${ }^{61}$ Kiško J., „E. Račius: pretekstas pulti Libiją buvo, tik klausimas, ar pakankamas?“, Balsas.lt, 2303 2011, http://www.balsas.lt/naujiena/530873/e-racius-pretekstas-pulti-libija-buvo-tik-klausimas-ar-pakankamas-video-foto, 26072011.

${ }^{62}$ Užsienio reikalų ministerija, „LR Ambasada Egipto Arabų Respublikoje, Jordanijos Hašimitų Karalystei, Sirijos Arabų Respublikai,Libano Respublikai, Kuveito valstybei, Jungtiniams Arabų Emyratams, Saudo Arabijos Karalystei ir Kataro Valstybei“, 0508 2011, http://www.urm.lt/popup2.php?tmpl_name=m_urm_ lt_embassy\&m_urm_country_id=57, 10082011.

${ }^{63}$ Lietuvos statistikos departamentas, "Eksportas, importas pagal valstybes", 1407 2011, http://www.stat. gov.lt/lt/pages/view/?id=2795, 31082011.
} 
reasons. First of all, the Arab uprisings became such a hot central topic that could not be avoided in the various international political forums (in particular - NATO and the EU). In addition, the pressure of the media interested in the so-called Arab spring played its part. Lithuanian politicians had to say something about an internationally important issue, because at the time of the uprisings Lithuania acted as the chairman of the Organization for Security and Co-operation in Europe and the Community of Democracies. In addition, one should not forget that Lithuania has had a somewhat similar experience to the Arab uprisings.

In 1988-1991 Lithuanians, Latvians and Estonians participated in the socalled singing revolutions. These singing revolutions in the case of the Baltic States resulted in transition from totalitarianism to liberal democracy. Lithuania even had its own Bouazizi - Romas Kalanta, who in the name of political protest set himself on fire in Kaunas in May $1972^{64}$. Still, the singing revolutions and Arab uprisings have important differences. The Arab uprisings have not acquired the clear ideological shape that the singing revolutions had. The collapse of communism in Eastern Europe has been total and relatively rapid. Despite the massive protests, many autocratic Arab regimes show no signs of collapse.

Lithuanian political leaders in their public speeches made statements related to the Arab uprisings, regardless of the fact that these statements were few in number. In general, it can be argued that Lithuania - with the experience of the singing revolution - was not very enthusiastic about Middle Eastern democratization. Lithuanian political observer Giedrius Cesnakas rightly points out that Lithuania has not used its politically advantageous position as chair of the OSCE and the Community of Democracies, to promote the spread of democracy in the Middle East ${ }^{65}$. However, it should be noted that lack of enthusiasm on the side of Lithuanian political leaders about Middle Eastern democratization should not be regarded as a mistake. Actually, it is wise to wait and see what happens next. Today no one knows for sure how everything will look in the Middle East in near future.

President Grybauskaite, who according to the constitution makes decisions on the basic issues of foreign policy and is responsible for the implementation of these decisions, pointed out that the Arab uprisings might have negative consequences for Lithuanian and European energy and economic security. The Lithuanian

\footnotetext{
${ }^{64}$ See: Hosking G. A., The First Socialist Society: A History of the Soviet Union from Within, USA: Harvard University Press, 1992, p. 433.

${ }^{65}$ Česnakas G., „Arabų revoliucijų fone - ką galetų nuveikti Lietuva?“, Delfi.lt, 2202 2011, http://www.delfi. lt/news/ringas/lit/gcesnakas-arabu-revoliuciju-fone-ka-galetu-nuveikti-lietuva.d?id=42308423, 24022011.
} 
president was concerned that the Arab uprisings would raise oil prices ${ }^{66}$. Lithuanian Defense Minister Rasa Jukneviciene pointed out that the uprisings in the Middle East could quickly and radically change the security situation in the periphery of the Alliance. According to her, it indicates that the Lithuanian security situation could deteriorate too ${ }^{67}$.

Lithuanian political leaders, in their public comments related to the Arab uprisings, devoted most of their attention to the Libyan uprising, where Western powers played an important role. Being a member of NATO Lithuania supported the leadership of the Alliance in implementing UN Security Council Resolution 1973. The key Lithuanian foreign policy-makers (president, prime minister, minister of foreign affairs) unanimously supported UN SC Resolution 1973. Still, all of them said that Lithuania had limited capabilities to take part in the enforcement of the resolution by military means. All of them rather spoke about Lithuanian participation in the operation limited to humanitarian assistance. However, even when talking about humanitarian assistance, they emphasized that Lithuanian resources are limited.

Of course, lack of resources was an important or even the most important obstacle for Lithuania to take a more active part in the Western military operation in Libya. However, there are other reasons for Lithuania's passivity. The relatively passive Lithuanian position regarding the Western military intervention in the Libyan uprising could be explained by the lack of Lithuanian interest related to this conflict ${ }^{68}$. According to Racius, the relatively passive stance towards the Libyan uprising by Lithuania is taken because it sees no tangible benefits that might come from the active support of the Western military operation in Libya ${ }^{69}$. Lithuania supported the U.S. led interventions in Afghanistan and Iraq because Lithuanian political leaders clearly saw the benefits of such support - better prospects to become a member of NATO and the EU.

Only one comment related to Libya, made by President Grybauskaite, attracted relatively significant attention from the local media. This comment was

\footnotetext{
${ }^{66}$ Prezidentès spaudos tarnyba, "Neramumai Šiaures Afrikoje - grèsmè ES ekonomikai“, 0803 2011, http:// www.president.lt/lt/spaudos_centras_392/pranesimai_spaudai/neramumai_siaures_afrikoje_gresme_es_ekonomikai.html?backlink=\%252Flt\%252Fpaieska\%252Fresults\%252Fp0.html, 01062011.

${ }^{67}$ Rasa Juknevičiené, „Septyneri Lietuvos metai Aljanse - mineti nereikia pamiršti“, 2903 2011, http://www. kam.lt/lt/naujienos_874/archyvas_930/ziniu_archyvas_2011_metai/ziniu_archyvas_2011___03/krasto_apsaugos_ministre_rasa_jukneviciene_septyneri_lietuvos_metai_aljanse_mineti_nereikia_pamirsti.html?backlin

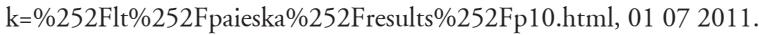

${ }^{68}$ Girnius K., “Užsienio politikos paieškos", Alfa.lt, 0205 2011, http://www.alfa.lt/straipsnis/11207662/ Uzsienio.politikos.paieskos=2011-05-02_08-03/, 02052011.

${ }^{69}$ Kiško J., „E. Račius: pretekstas pulti Libiją buvo, tik klausimas, ar pakankamas?“, Balsas.lt, 2303 2011, http://www.balsas.lt/naujiena/530873/e-racius-pretekstas-pulti-libija-buvo-tik-klausimas-ar-pakankamasvideo-foto, 26072011.
} 
made during her interview to the Austrian newspaper "Die Presse". In the interview the Lithuanian president noted that Western military operations in Libya exceeded the UN mandate ${ }^{70}$. The Lithuanian president wanted to know why Western powers decided to intervene in the Libyan conflict. She remarked that southern Africa is full of dictators and Lithuanian political observers immediately criticized the president's comment on Libya. They equated her position on Western military involvement in the uprising in Libya to the one taken by Russian Prime Minister Vladimir Putin ${ }^{71}$. Commenting on Grybauskaite's interview with "Die Presse", political observer Kestutis Girnius noted that Lithuanian political leaders revealed a lack of co-ordination on foreign policy issues ${ }^{72}$. It is difficult to disagree with Girnius on this judgment. The Lithuanian prime minister and minister of defense often highlighted the importance of NATO and Western solidarity ${ }^{73}$. Grybauskaite's comment on Western involvement in Libya is clearly at odds with NATO's solidarity. One should remember that Lithuania officially had agreed that the implementation of Resolution 1973 would be taken by NATO.

Grybauskaite's remark that Western military operations in Libya exceeded the UN mandate did not attract much attention abroad. This may be the indication that Lithuania is a small and non-influential Western country. Of course, one should also remember that the position of the Lithuanian president was in line with the official stance of an influential Western country, Germany.

Lithuania is not related to the Middle East region by historical, political and economic ties. Because of that the impact of the Arab uprisings on Lithuania is likely to be small and indirect. The main disadvantage related to the Arab uprisings and Lithuanian security might be higher oil prices. These might create troubles

\footnotetext{
${ }^{70}$ Prezidentés spaudos tarnyba, "Prezidentès Dalios Grybauskaités interviu Austrijos dienrǎ̌čiui "Die Presse": „Operacija Libijoje peržengia JT mandatą“, 2011, http://www.president.lt/lt/prezidento_veikla/prezidente_ziniasklaidoje/interviu_385/prezidentes_dalios_grybauskaites_interviu_austrijos_dienrasciui_die_presse_operacija_libijoje_perzengia_jt_mandata.html?backlink=\%252Flt\%252Fpaieska\%252Fresults\%252Fp0.html, 01 062011.

${ }^{71}$ Prezidentès spaudos tarnyba, " Neramumai Šiaurès Afrikoje - grésmè ES ekonomikai“, 0803 2011, http:// www.president.lt/lt/spaudos_centras_392/pranesimai_spaudai/neramumai_siaures_afrikoje_gresme_es_ekonomikai.html?backlink=\%252Flt\%252Fpaieska\%252Fresults\%252Fp0.html, 01062011.

${ }^{72}$ See: Navickaite R., ,NATO kritikai - V.Putinas ir D.Grybauskaite“, IQ.lt, 3004 2011, http://iq.lt/ titulinis/d-grybauskaitei-uzkliuvo-nato-atakos-libijoje/, 01062011.

${ }^{73}$ Vakarų ekspresas, „Andrius Kubilius: Lietuva prie veiksmų Libijoje neprisidès“, 2303 2011, http://www. ve.lt/naujienos/lietuva/lietuvos-naujienos/andrius-kubilius-lietuva-prie-veiksmu-libijoje-neprisides-565420/, 0407 2011; Rasa Juknevičienè, „Septyneri Lietuvos metai Aljanse - minèti nereikia pamiršti“, 2903 2011, http://www.kam.lt/lt/naujienos_874/archyvas_930/ziniu_archyvas_2011_metai/ziniu_archyvas_2011_-_03/ krasto_apsaugos_ministre_rasa_jukneviciene_septyneri_lietuvos_metai_aljanse_mineti_nereikia_pamirsti.html?backlink=\%252Flt\%252Fpaieska\%252Fresults\%252Fp10.html, 0107 2011; Diena.lt (BNS), „R.Juknevičienè: NATO sausumos operacija Libijoje nę̨sivaizduojama“, Diena.lt, 0806 2011, http://www. diena.lt/naujienos/uzsienis/r-jukneviciene-nato-sausumos-operacija-libijoje-neisivaizduojama-357318/skelbimai/skelbimai/komentarai, 07072011.
} 
for Lithuania's economic and energy security. Most likely, the Arab uprisings will not have a significant impact on Lithuania's participation in the Global War on Terror and localized counter-terrorist operations. In addition, Lithuania is quite unlikely to receive significant numbers of Middle Eastern immigrants. Their main destination point is usually the wealthier countries in Western Europe.

The Arab uprisings could be of greater significance for the Lithuanian national security only if a possible domino effect should occur, stretching out the boundaries of the Middle East. There are countries that are of importance for Lithuanian security and they might experience uprisings resembling those in the Middle East. Political and social conditions in these countries might look familiar to those in Tunisia, Egypt, and Libya. Many countries in Central Asia seem ready to explode in the same way the Middle Eastern Arab countries did. Kyrgyzstan, Tajikistan and Uzbekistan are included in the failed state list published by the magazine Foreign Policy and the Fund for Peace ${ }^{74}$. A single desperate act of protest might trigger an uprising against Alexander Lukashenko's autocratic regime. Surprisingly, it may turn out that the police state managed by Vladimir Putin and his siloviki is much more vulnerable than it may seem.

In summary, it is important to note that uprisings in the form of politically loaded mass protests are not somehow unique to the Middle East. Bouazizi is not the first one to set himself on fire in the name of protest. It is obvious that he is not the last one. Lithuanian and other Western security experts have a lesson to learn from the Arab uprisings. They should expect unexpected uprisings in unexpected places.

\section{Conclusions}

At this time it is very difficult to assess the impact of the Arab uprisings on the security interests of the West and Lithuania. The Arab uprisings are an on-going process. In many cases the results of the uprisings are inconclusive. The players participating in the uprisings are unpredictable. The real consequences of the Arab uprisings on Western and Lithuanian security interests may appear only after a few years or several decades.

So far, it is clear that the Arab uprisings are events of strategic importance. The Arab uprisings have already started to change the balance of power in the Middle East region. This region is becoming less stable. Because of the Arab upri-

\footnotetext{
${ }^{74}$ Foreign Policy, „The Failed States Index 2011“, http://www.foreignpolicy.com/articles/2011/06/17/2011_ failed_states_index_interactive_map_and_rankings, 31082011.
} 
sings, the major Western countries need to review their policies towards the Middle Eastern countries. Washington, London and Paris-based policy makers, who are responsible for the formation of foreign policy, are still looking for relationship patterns and for solutions for how to deal with the Middle Eastern dictators and the protesters.

It seems that after the Arab uprisings the West will have no time to rest and to forget about the Middle East. For the Western countries it might be more difficult to achieve the continuity of oil supplies. Cooperation with Arab countries on various security issues is becoming more complicated. In particular, WesternMiddle Eastern cooperation in the fight against terrorism may suffer.

Lithuania has no close historical, political or economic ties with the Middle East. Because of that the Arab uprisings have no direct effect on the security situation in Lithuania. Even complicated Western-Middle Eastern cooperation in the fight against terrorism should not have a great effect on the security of Lithuania.

The most pressing problems of the Arab uprisings for Lithuanian national security are related to the country's economic and energy security. How harmful can the Arab uprisings really be for Lithuania, which is dependent on Russian energy resources? In general, analysis of the statements of Lithuanian political leaders on the Arab uprisings revealed that the Lithuanian stance towards the Arab uprisings is determined by the local realpolitik protagonists, rather than by idealistically minded liberals and democracy advocates. Bearing in mind the fact that Lithuania is a small country with scarce human and material resources for security and foreign policy implementation, this is not such a bad thing.

The Arab uprisings could become a really big issue for Lithuania only if a domino effect were to stretch out the boundaries of the Middle East. After the unexpected Arab uprisings, the concerns about stability in the Lithuanian neighborhood (Belarus and Russia) and Central Asia are more valid. Regimes in these countries by various criteria resemble those that not so long ago existed in Tunisia, Egypt and Libya.

Vilnius, July-August 2011 